\title{
IT is Enabler of Business in a Turbulent Market Place
}

\author{
Tesfahun Tegegn \\ Wolaita Sodo University
}

\begin{abstract}
Technology is fast becoming available to all, from start-up entrepreneurs to established businesses across all sectors, similarly government and academia. So the potential as a significant game changer cannot be underestimated. However, in this fragile market environment whenever there is change with regards to demand and also preference, whenever the loyalty of the customers is in a position that will undermine the business organization, whenever the by seeing a given business company is skimming the profit due to the uniqueness of the product then it is the time organizations should look for the need for information technology in order to sustain the existing business environment and adopting so as to cope up with the fragility of the environment. Yes, it is true that IT enables the turbulent market to adjust the strategies and act accordingly to even survive let alone to compete and make profit.
\end{abstract}

DOI: $10.7176 / \mathrm{IKM} / 9-4-05$

Publication date: April $30^{\text {th }} 2019$

\section{Introduction}

Market Turbulence is the rate of change in the composition of customers and their preferences. The following are believed to be The Cause of Market Turbulence

An unstable economic climate, ever changing customer needs, and up-and-coming technology continually stirs up market turbulence. The driving force in this new marketplace is the consumer. The driving factor is technology

Our world is changing; customers are more demanding they want: new, innovative products, increased availability, shorter lead-times, and increased differentiation of product/service, better quality and most of all, at the same price!

\section{IT as enabler}

Information Technology [IT] is not the business, it is an enabler. That being said, there are businesses' where Information Technology is the prime area of the business but the business process is different for each. By enabling the business, I am noting that the IT strategy, architecture and projects should be dictated by the business strategy, architecture and programs.

Often seen disconnect between these or that the IT strategy is driven by an IT project.

It is also my opinion that IT is perceived as not providing value to the organization. Why is this? Industry critics have noted that:

Inhibitor to corporate progress - IT systems cannot be changed fast enough to meet market demands, seize opportunity or comply with a new requirement.

Weak alignment between IT and business strategy - marked by an intractable language barrier.

Not strategically aligned - IT does not know or follow corporate strategy.

IT is almost never the source of innovations.

\section{IT as a Strategic Enabler- Creating Sustainable Advantage}

Sustainable advantage occurs only when a company embraces the fact that change is inevitable and accepts that Demand drives Supply. This is true even when Demand is invented. So how will sustainable advantage work in general when the products and services might be less flashy?

Sustainable advantage requires an organization to be agile at its core. That means all stakeholders on the business side need relevant and timely market facing information, they need to be able to analyze data, hypothesize outcomes and try out ideas quickly.

\section{The IT function's role:}

Trends in Big Data make it clear how important deep data analysis is becoming. IT needs to make it easier to access, aggregate, and create models that can be shared and visualized. The IT function must enhance the ability of employees to access this data in its various stages (raw, analyzed and historical). Make it possible for the business to craft their findings into actionable directives that can eventually be used to guide or configure changes in the way that IT works.

The IT function must continue to enhance collaboration across time zones and boundaries.

This is not just a matter of telecommunication, but of information and knowledge lifecycle management. 
Organizations are drowning in a digital morass of unstructured aging data. Outdated data can be very dangerous to an agile organization.

Business Agility occurs when processes and rules can be changed, added, and retired. Since IT is often the face of the company to the outside world, that currently means that process and rule changes need to be coded and carefully tested for very long periods of time. Radical changes might have to be parallel tested for an entire quarter.

\section{The IT function's role:}

Identify applications associated with key revenue and client facing responsibilities.

Collaborate with the business to externalize rules, making them editable by the business

while remaining auditable. Allow the business to create co nfigurable process flows which can be accepted by the IT application managers.

Revise the current requirements process to directly address business volatility

Sustainable advantage respects the fact that Demand fluctuates according to market dynamics. Sometimes those dynamics are seasonal. Other times Demand is more of a gold rush experiment (e.g. ten competitor's attack a market niche at once and 2 years later there are 2 survivors).

\section{The IT function's role:}

[1] Provide robust, Purpose Built Infrastructure, that can be configured by defined business policy and run according to business needs.

[2] Enable dynamic Demand based provisioning and repurposing so that infrastructure is not wasted.

[3] Remove the overhead of building robust infrastructure for experimental applications.

[4] Encourage IT and Business alignment through the proactive creation of a portfolio management discipline. Sustainable Advantage occurs when businesses can make intelligent decisions about when to cut their losses and where to direct their investments, based upon current and expected revenue. When a business is running blind regarding their expenditures, and potential risks, they become conservative because they have legitimate fears about harming their brand.

\section{The IT function's role:}

Creating an active current state inventory across all data centers for all business critical applications. This task force should be highly regarded, charted with advancing the forensic discipline across the company.

Make IT financial reporting meaningful to the business by relating IT expenditures to revenue, cost avoidance, agility, and support of new markets.

No matter the organizations are today in digital transformation journey and facing with turbulent market environment, here are some steps the business organization should position IT as a digital business enabler:

1. Establish a cloud strategy and execute it.

2. Assimilate with other Lines of Business to connect with business drivers, to understand business processes outside of IT, and to align technology decisions with customer experience.

3. Refine communication and collaboration capabilities. Both innovation and efficiency rely on breaking down barriers, connecting talent across the enterprise, and collaborating to cultivate and develop ideas.

4. Review the technology investments and make sure you're consuming the features of the products that already implemented. And make sure those capabilities are linked to business outcomes to resist the fragile or turbulent market.

5. Ensure that all technology decisions you make - including products and services purchased as well as designs selected - are not overly complex, are easy to manage, and integrate with other applications.

\section{Conclusion}

IT leaders end up providing data, information and alerts so that business leaders can take actions. These actions can be corrective or preventive. IT teams should have a business aligned mind set to cope up with a turbulent market the can even destroy the organizations existence. It is very well known that IT has turned the tables, but the fact remains that majority of times, IT works efficiently to honor a decision taken by management or works to enable a smooth transition. All these are aiding the decision, not influencing the decision to turn things to the benefit of the organization by coping up the fragile market that businesses do face these days.

\section{Bibliography}

[1]Bill Evans. Digital Transformation - IT as a Dig ital Business Enabler [On line].April 29, 2016 [accessed.11.January 2017] Retrieved z: http://www.ep lus.com/More-Perspective/Pages/DigitalTransformation-IT -as-a-Dig ital-Business-Enabler.aspx\#.WHu zetIrLIU. 
[2] Scott Alan Miller. Is Your IT Depart ment a Hobby Shop or a Business Enabler? [On line].April 29, 2016 [accessed.11 .January 2017] Retrieved z: http://www.storagecraft.com/blog/it-hobby-or-business/.

[3] Viral Raval. IT as a business enabler? So me hard facts [Online].September 19, 2014 [accessed.14 .January 2017] Retrieved z: https://www.linkedin.co m/pulse/20140919082353-4138806-it -as-a-business -enablersome-hard-facts.

[4]Richard Skriletz. How to Make IT a Business Enabler [On line].March 19, 2013[accessed.13 .January 2017] Retrieved z: http://www.b-eye-network.co m/view/16788. 